\title{
Owning 'Myth': Conceptual Considerations
}

\author{
Ivan Strenski
}

University of California, Riverside

\begin{abstract}
Conceptual critique of the concept of myth should be a priority for anyone using the word in scholarship. A critical attitude to "myth," first, consists in becoming aware that the term trades on the Greek, "mythos." Second, a critical approach recognizes the great range of uses of the term, from its hypothesized, upper-case form — "Myth" - to a variety of less exalted uses in lower case — "myth" or "myths." No common referent necessarily exists of the diverse uses of these terms. Each use will tend to have its own rationale for faithfully representing how one should use the term. After one submits a given use of "myth" to critical chastening, the term can then be used in cultural and social research. For example, one recommended use of "myth" might be "important story."
\end{abstract}

\section{Keywords}

Conceptual critique; Theory; Myth; Responsibility; Rorty; Stories; Alternative histories;

\section{Contact Address}

Professor Ivan Strenski, Holstein Family \& Community Distinguished Professor of Religious Studies, University of California, Riverside, United States, strenskila@gmail.com

\section{Myth Trouble}

In a way, conceptual difficulties with the word 'myth' begin with the notorious problems attending translation from one natural language to another. 'Mythos' is not our word, but 'theirs'. In his Theorizing Myth, Bruce Lincoln, for one, sketches a convincing genealogy of 'mythos', tracing it from the Greeks into its many later uses. But, he rejects, out of hand, defining any concept of 'myth' - even, I believe, the one, or ones, he has fruitfully used over the course of his career. Instead, Lincoln gracefully slips into his familiar practice of discourse analysis. He writes about 'myth' in Theorizing Myth, in order to "elucidate some of the ways" the "word, concept, and category have been used and to identify the most 
dramatic shifts that occurred in their status and usage". ${ }^{1}$ All well, good and illuminating. But, Lincoln's historical work leaves to one side both inquiry into how concepts of 'myth' articulate within a theory of myth, and whether or not we might come to a consensus about a serviceable concept of myth for religious studies.

Notably, Lincoln even assumes that the term, 'myth', should be retained. Unlike 'phlogiston' or 'the humours', 'myth' ought not be dumped onto the ash-heap of history. Nor, should we make a cottage industry of its elimination, as some of our better-known colleagues have done of eliminating the term, 'religion'. While good arguments can always be made for eliminating the term, 'myth', I think it has a future. In this paper, I propose both to explore the way concepts like myth articulate with theory and, then - fearlessly, or foolishly, as the case may be-propose a serviceable concept of myth for the study of religion.

In terms of the most basic conceptual issues, the trouble with myth begins as soon as we open our mouths, and say that first—loaded—word: 'Myth'. Is it, for example, upper or lower case? Is it singular or plural? And, what do these differences mean? Take uppercase uses first.

\section{Some thoughts about using 'Myth' in the upper-case}

1. People who speak of (or speak with) something called 'myth', in the upper-case, seem to be talking about...

i. some sort of unique, autonomous, universal or general (and uncontroversial) metaphysical principle or phenomenon, often abstracted more concrete media, such as a story e.g., "Hitler exploited the awesome, innate power of myth", or the Bill Moyers-Joseph Campbell, TV series, The Power of Myth.

ii. some class of value abstractions or qualities having either an elevating or diminishing character-

2. such as, in the way people believe that art, magic, power, style, are elevating. e.g., "Instead of being a dull and prosaic documentary, this film works because it is infused with myth".

3. Or, on the other — diminishing — hand, in the way 'myth' is said to be false, confusing, illogical, crude, 'primitive': e.g. "Instead of helping us to understand Ronald Reagan, this documentary was shot through with myth".

i. In appealing to 'Myth', a certain contrast is presumed — by definition-with other similarly hypostasized entities: Myth, thus, variously contrasts with history, religion, science, revelation, ritual, literature, philosophy, truth....-again all entities regarded as fundamentally simple, objective and uncontestable, e.g. "The problem with the modern world of science is its elimination of myth". Or, "The Bible is revelation, not myth”. Or, Ernst Cassirer's book, Myth and Language

${ }^{1}$ Lincoln, Bruce. Theorizing Myth. (Chicago: University of Chicago Press), 1999, 9. 


\section{Why I Won't Miss 'Myth' (Upper-case)}

Speaking of such principles, as Myth (upper-case)—in terms of lofty hypostasized entities-ironically, results in profoundly superficial discourse. Does anyone think that anything of consequence can be engaged, for example, by posing questions at the level of Science versus Religion, for example? Relying upon such hypostasized entities is what gives the polemic of a Richard Dawkins, for example, its peculiarly antique flavour. We just know too much about the variety of possible references underlying such upper-cased as Myth or Religion or Science to be content to carry on at that level. These upper-cased terms are, at best, rubrics, headlines or useful shorthand for a host of conflicts fruitfully sorted out in terms of the specific problems for which these sweeping generalizations are supposed to stand. So, that's why I won't miss speaking of upper-case Myth. It's not where the action is.

\section{What Then to Do about 'myth' and 'myths'?}

Once we put aside speaking of upper-case 'Myth', where does this leave speaking about lower case 'myth' in singular or plural? It leaves us, I would submit, precisely where every knowledge worker in history has been left-facing choices of how to fashion our language so that we can make consequential claims about the world.

Let me appeal to a choice made in one of the greatest works in the study of religion, Max Weber's Protestant Ethic and the Spirit of Capitalism. As we all know, Weber sought to argue for a certain relation between religion and the economic system, commonly known as 'capitalism'. But, in articulating this relationship, Weber applied two different standards to the terms, religion and capitalism. On the one hand, Weber took responsibility for a precise concept of capitalism. Weber required a sharply defined analytic sense of the term, 'capitalism' in order to undertake the work of his masterpiece. He was unwilling to surrender responsibility for his concept of capitalism to ordinary, everyday, possibly confused usage. Instead, he delimited his conception very sharply and specifically, distinguishing it from a host of meanings circulating in everyday speech. He was unwilling to accept responsibility for speaking of capitalists in the same breath as one would speak of brigands and pirates, or those inheriting or simply enjoying great wealth. He was committed to another set of defining properties to mark what he felt was consequential and distinctive about this thing he wanted to call 'capitalism'. And, so Weber took a risk, and assumed responsibility for using the word, 'capitalism' in a precise and delimited way. In this, he followed the well-trodden path of knowledge workers who devise scientific terminology, at least ever since Sir Isaac Newton borrowed the term 'force' from its innumerable, every day, vague common uses. 


\section{“Religion” and 'Myth': Responsible or Irresponsible?}

By contrast, Weber made an entirely different decision when it came to 'religion'. He surrendered responsibility for his concept of religion to ordinary usage. Religion named a class of objects that was composed of Buddhism, Judaism, Brahmanism, Christianity, Roman Catholicism, Pietism, Lutheranism, Quakerism, etc.—basically a list anyone could assemble by heading to the Yellow Pages of the phone book (if anyone here remembers such things.) As scrupulous as Weber was about being responsible for his concept of capitalism, he was just as irresponsible about his ownership for a concept of religion. 'Religion' was just 'taken off the shelf', so to speak, almost casually, like an LA shopper at Whole Foods might take whatever low-fat Kefir was handy. Weber delegated his conception of religion to ordinary usage.

When I wrote Four Theories of Myth in $20^{\text {th }}$ Century History, I was also surprised by the same lack of critical, conceptual self-awareness among highly touted theorists of 'myth'. What, instead, impressed me was their tendency just to take the word 'myth' and the folk concept of myth, as Weber did for religion, 'off the shelf' - even if the 'shelf' in question was made up of particular taken-for-granted meanings the word, 'myth', current in a particular context. I argued, for instance, that Cassirer or Eliade's senses of myth were variously reflected the deployments of nationalist and racist discourses. The moral of this story is that if we just inform our theories of myth with what common-sense or theoretical fancy have to say about lower case 'myth', we get a Rorschach splash of meanings, where it is left to the reader to pick and choose according to one's, typically unreflective, appetites.

\section{How, Then, to Be Critical of and/or Responsible for a Concept of 'Myth'?}

a) Being critical about the use of word such as 'capitalism', 'force'-- and, yes, 'myth', toowould mean assuming responsibility for a particular sense of the term: not every use of the term will do. For 'myth', I shall argue that 'story' is a sense of 'myth', for which it would be worthwhile taking responsibility.

b) Of course, simply being responsible for one's concepts does not guarantee anything in itself. Some scholars, for example, have taken responsibility for a hypostasized, metaphysical notion of myth - the 'upper-case Myth'. But, what if this responsibility were misplaced? If, as I have argued, no such thing as upper-case Myth exists, buying into and thus owning it, would amount to being sold a false bill of goods. At best, such discourse deploys the language of rubric, headline and short-cut, not a durable or fruitful discourse about/of myth. But, more than Lincoln, I shall propose that there may be-at least - one concept of 'myth' worth owning, one worthy of the responsibility we might take for it.

c) Being responsible for a particular use of the word, 'force', and so too, 'myth', would then mean requiring us to defend or justify that usage. What most myth theorists miss is the possibility that there is no such objective reality out there to which the word, 
'myth' corresponds. But if we cannot measure our use of the word, 'myth' against its correspondence to objective reality, how can we defensibly adopt a given meaning for the word? I am proposing that we adopt Richard Rorty's 'pragmatist"' approach to this question. ${ }^{2}$ Accordingly, one recommends a given use of the word 'myth' in terms of the tasks one wishes its use to achieve. The 'true' sense of 'myth' is that which aids one in performing specific tasks. Does the sense of 'myth' Malinowski propose make a difference to actual practices? Is it useful for solving any problems? How does it move our understanding of culture further along? Malinowski's concept of 'myth' is simply a 'tool' for our getting certain projects done.

d) Rorty's general epistemological approach superficially resembles Malinowski's pragmatic approach to myth. But Malinowski differs radically from Rorty in still imagining that he had discovered the objective reality to which the word 'myth' corresponds. Malinowski's theory of myth may be a pragmatist one, but his epistemology remains Platonist. Malinowski is convinced he knows objectively what to look for in seeking 'myth' in his classic fieldwork on the Trobriand islands. What he says 'myth' is true to the extent it mirrors the ideal — essentially Platonic — form, Myth. Although the Trobriand languages do not include the word, 'myth', Malinowski simply dictates that the Trobriand word, ' 'iliu' means what the European word 'myth' means to him. Myths are special. They are not idle tales or legends. Instead, as Malinowski tells us with masterly assurance, that myth "comes into play when rite, ceremony, or a social or moral rule demands justification, warrant of antiquity, reality, and sanctity." " "These stories live not by idle interest, not as fictitious or even as true narratives; but are to the natives a statement of a primeval, greater, and more relevant reality, by which the present life, fates, and activities of mankind are determined." ${ }^{4}$ In Rorty's language, a Malinowskian could defend the use of the word, 'myth' as 'warrant', charter, and so on because in doing so, he achieves certain desired ends.

e) Rorty defends his approach as consistent with the classic approaches of the great scientists, such as Isaac Newton. While it is true that Newton still operated in the Platonic epistemological world, his theoretical conclusions can be explained from Rorty's pragmatist viewpoint. Thus, Newton's conception of 'force' succeeds, for example, because it provides him with a tool to accomplish a number of desired ends-explaining the laws of motion and universal gravitation. It does quite adequately in accounting for the movement of the planets, the ocean's tides, the trajectories of comets and so on. But Newton's physics is useless for explaining reality at the atomic and sub-atomic levels. It is the wrong tool for use in splitting the atom. For that tool, we need to wait for

\footnotetext{
${ }^{2}$ Rorty, Richard. Philosophy and Social Hope. (London: Penguin), 2000.

${ }^{3}$ Malinowski, Bronislaw. "Magic, Science and Religion." In Magic, Science and Religion, edited by R. Redfield. (New York City: Doubleday), 1948, 84-85.

${ }^{4}$ Faublé, Jacques, and Urbain-Faublé, Marcelle. "Notes sur des travaux d'ethnologie et d'anthropologie." L'Année sociologique, no. 23 (1972), 108; Malinowski, Bronislaw. "Magic, Science and Religion." In Magic, Science and Religion, edited by R. Redfield. (New York City: Doubleday), 1948, 84-85.
} 
the likes of Niels Bohr and the Copenhagen School, Albert Einstein and the theory of general relativity.

f) We know how Newtonian 'forces' are measured. But, the measure of its location within a coherent view of reality or theory emerges when we see how Newton committed himself to the understanding of 'force' as the product of 'mass' times 'acceleration'. These conceptual interrelations imply that Newton had assumed responsibility for a total picture of reality in the process - what we call the theory of Newtonian physics. Likewise, when we mark 'myth', we too are implicated in theory, even if we may resist articulating it further, even if we resist pursuing the entailments of conceiving myth in a certain way. Any conception of 'myth' will share the same conceptual space with other interrelated terms, even if one resists pursuing those entailments. Like any significant choice in human affairs, conceiving myth in a certain way has consequences-whether or not we wish to pursue them. In the past, for example, some theorists conceived 'myths' as occupying the same conceptual space as 'dreams' or 'symbols' or 'rituals'. These notions were theoretically linked as surely as 'mass', 'acceleration' and 'force'. A 'theory' of myth would simply articulate how these notions were related.

g) Weber also explicates his project in The Protestant Ethic in terms of its use to serve the larger purposes of promoting an overall idealist theory of culture, expressly articulating a viewpoint of the way values, legitimations, beliefs and such make a difference to the formation of societies. The religious roots of capitalism are grounded in a larger vision of the way 'ideas' legitimize, and thus ground, social institutions, such as an economic system. Likewise, students of myth theories need to ask into what larger projects does 'myth', as variously conceived, fit? Someone like Bruce Lincoln, for instance, situates myths within his more encompassing vision of discourse and its destiny, which in turn, would serve as a tool for furthering Lincoln's neo-Marxist world-view of the good.

h) Finally, religious studies is a discipline that is supposed to be about something in the world - what the Kantians called a 'synthetic' discipline. Therefore, the ultimate worth of criticism of its categories, such as 'myth', does not lie in the act of criticism in itself, alone. Criticism of categories in 'synthetic' endeavours shows its worth if they serve as efficient tools for promoting fruitful understandings and explanations of the world. Yes, one does accrue moral merit for being responsible for one's concepts. But, merely to have taken responsibility for one's concepts is not the end of the story. We still would need to show that the risk in so doing was worthwhile-that it makes a difference. How does a concept of myth, thus critically constructed, help us make consequential claims about the world? Of what value would Weber's fretting over the concept of capitalism have had, if it had not issued in consequential claims about the world? Agree or disagree with Weber, the 'Weber thesis' has borne abundant fruit.

Let me conclude by proposing a concept of myth that might form the basis for possible consensus, and that might minimize some of the confusion attending the various theorizations and conceptualizations of myth. 


\section{'Important Stories': A Basis for a Conceptual Consensus?}

I have lately been working in the troublesome, but opaque world of religiously inflected politics. Circulating in today's Russia, for instance, we meet an entire literature of 'alternative histories', well-documented and presented as massive work of erudition. ${ }^{5}$ These heavily documented tomes generate certain ready-to-hand narratives of Russia's history, both ancient and modern. Russia single-handed saved Europe from the Nazis, who moreover are attempting to re-emerge in Ukrainian rightist movements, like the Right Sector militia. Signs of the resurrection of the once discredited myth of Moscow, Third Rome, and thus the true centre of the Christian world, once more inform political rhetoric, here and there. Or, as if to affirm Russia's unique place between East and West, she asserts her place as a Eurasian power, but not only that. Russia's long domination by the Mongols indelibly shaped her deepest political and social identity. These Eurasianist narratives, thus, proudly identify, Russia with specifically Mongolian formations, leaving its European character adrift.

What matters for understanding 'myth' in the sense I seek to elaborate is these oral and/or less than formal 'tellings' of the major theses of the formidable 'alternative histories'. Even though the brisk sales of these 'histories' indicate a large readership, we must imagine that in reality, only a few people carefully read these weighty tomes spelling out these theories of Russian history. But, everybody knows their 'stories'. Everyone knows what 'myth' the books deploy, in the form of ready-to-hand narratives that can be easily recited or presumed as part of the repertoire of folk-wisdom.

In this, the relation of these Russian 'myths' to the massively documented works of scholarship of Russia's Eurasian nature, for instance, follows a widespread pattern. In apparent agreement with my thesis, one of my colleagues responded by noting that he found evidence in modern-day politics of the same myth-making. He cited the example of some Turks who claimed that Ottoman responsibility for the 1915 Armenian genocide was a 'myth'. I quickly made myself better understood by responding that I was not using 'myth' as a label for a falsehood, as his example did, and as is commonplace still. Rather, the 'myth' was in the telling, retelling, in the casting and recasting in an endless string of variants, in the circulation and popularity of a ready-to-hand 'story'," intending to capture the gist of the massive store of historical and contemporary documentation of the case on either side in this conflict. The 'myth' was in the 'stories' told and what those stories effected in their audiences, not the documentation amassed, even if myths drew upon such documentation (or, of course, pseudo-documentation). So, as well, were 'myths' of Armenian survivors and offspring - the ready-to-hand or remembered narrative accounts of the horrors of being separated from family, of summary execution, of expropriation and certain death in inhospitable deserts. It would be left to a later generation of scholars

\footnotetext{
${ }^{5}$ Laruelle, Marlène. "Le néo-eurasisme russe. L'empire après l'empire?" Cahiers du Monde russe 42, no.1 (2001):71-94; Laruelle, Marlène. Russian Eurasianism: An Ideology of Empire. Washington, DC: Woodrow Wilson Center Press, 2010; Sheiko, Konstantin, and Stephen Brown, eds. History as Therapy: Alternate History and Nationalist Imaginings in Russia, 1991-2014. Stuttgart: ibidem, 2014.
} 
to document the details of what these stories tried to convey together with the results of heroic work in archives and others stores of official memory. But, I am putting forth the notion that 'myths' and such scholarly 'documentation' are two different things, even if claims made in 'myths' may be 'documented'. The oral, or less than formal telling, retelling, writing and rewriting, in an endless stream of variants- 'myths' - do not 'document' important events. 'Histories', empirical, perhaps statistical, research do. 'Myths' tell about them, and in doing so ideally make a difference.

Now, because these stories are marked by their widespread importance, I have been tempted to mark them as well. I think they might be usefully organized under the rubric, of 'myth'. Religious studies may have something special to offer treatments of the phenomenon of 'alternative histories', because existing treatments seem noticeably, and familiarly, deficient. Some historians seem just unable to admit the recrudescence of such narratives as the hyper-nationalistic Moscow, Third Rome, for instance. It does not seem to fall into the model of progressive modernization they tacitly assume, even in the face of Putin's determined remaking of the Russian soul. Others fall back on psychoanalytic models. For them, these 'alternative histories' are simply 'therapy' for the sick post-Soviet mind seeking solace for the loss of empire. ${ }^{6}$ Russians are simply mentally ill, irrational and so on, and in massive numbers.

Students of religion should find that such dismissive discourses have a familiar ring. How often we meet in both learned and mass media the libel that various religious phenomena are labelled as 'pre/ill-logical', 'crazy' or 'irrational' and so on! Waco, Peoples Temple, Heaven's Gate, Scientology, Karen Brown's Voudon, so-called 'suicide bombers', and now ISIS? Our best responses to this kind of dismissive analysis has been to bring out the hidden logic in so-called 'illogical' or 'crazy' beliefs and practices. We can do this because many of us have been trained in the kind of rigorous methods of understanding, as say spelt out by Charles Taylor. ${ }^{7}$ Taylor takes to task both the pious notion that the insider always enjoys a privileged, incorrigible, access to their actions and motivations, and the soft version of understanding by way of 'empathy', as a kind of mind reading. Most important of all, he forces attempts to grasp the point of view of others to argue for their conclusions, to give an account of themselves. Attempts at understanding must be seen, then, as 'corrigible', and thus testable.

I believe the beginning of understanding these 'alternative histories' is to take them on as marked, as 'important stories', as 'myths'. Like other marked stories, 'jokes', for example, they are told and retold in endless numbers of versions. They circulate and have currency. These sorts of stories either exist or they do not. Determining whether they do or not is

\footnotetext{
${ }^{6}$ Sheiko, Konstantin, and Stephen Brown, eds. History as Therapy: Alternate History and Nationalist Imaginings in Russia, 1991-2014. Stuttgart: ibidem, 2014.

7 Taylor, Charles. "Interpretation and the Sciences of Man." In Philosophy and the Human Sciences: Philosophical Papers, edited by C. Taylor, 15-57. Cambridge: Cambridge University Press, 1985; Taylor, Charles. "Understanding and Ethnocentricity." In Philosophy and the Human Sciences: Philosophical Papers, edited by C. Taylor, 116-33. Cambridge: Cambridge University Press, 1985.
} 
a straightforward job of mainline empirical social research. Do societies judge certain stories to be 'important' or not? Determining how and why is something done by normal procedures of social research. Part of an answer - worth testing — for example, why a given story is judged 'important', and thus rises to the level of a 'myth', might be that these 'myths', like all good stories, tap into the resources of the imagination and memory. But, our work only begins here. What does it mean that the 'myths' win their 'importance' by "tapping into the imagination or memory", exactly, and how do they do so? As marked stories, I am tempted to argue that they also circulate in society and have life of their own; they are told and retold, and so on in many versions. But, again, by what mechanisms do they do so? Like good jokes, I would argue as well that they 'catch' on. But, again, and how do they do so? Furthermore, they provide a sense of wholeness-for instance, a story of the nation's past history and future destiny-from beginning to middle and end. Or, they recall that the nation's story is open-ended, and lacks a neat picture of its 'end'. In either case, the constructed nature of stories might enable people to achieve a complete and/or defensible sense of their nation's place in the world. But, again, and finally, how do they do so? These are only a few of the reasons that I am finding the notion of a 'marked' or an 'important story' - 'myth' - an intriguing heuristic tool. Despite confusion about definition and despite a history of ramshackle scholarship, I find the term useful, and perhaps indispensable to religious research.

Because they have properties that differ from standard prosaic speech, stories present special cases of communication. As Lévi-Strauss once said, people tell stories or myths quite often to communicate in deliberately suggestive or indirect ways. This does not mean they aren't capable of straightforward prosaic speech, only that the matters about which they speak are better spoken indirectly through suggestion rather than directly and explicitly. This points to the idea that many concerns that are at the heart of a society are not the kinds of things about which one can or will speak prosaically and directly. They must be inferred or left open to broad interpretation, rather than narrowed into a simple statement. Perhaps this means that societies, nations, for example, do their business tacitly, just as individuals do. Stories, important stories or 'myths' are where that business is done, but tacitly.

\section{Bibliography}

Faublé, Jacques, and Urbain-Faublé, Marcelle. "Notes sur des travaux d'ethnologie et d'anthropologie." L’Année sociologique, no. 23 (1972): 303-315.

Laruelle, Marlène. “Le néo-eurasisme russe. L'empire après l'empire?” Cahiers du Monde russe 42, no.1 (2001):71-94.

Laruelle, Marlène. Russian Eurasianism: An Ideology of Empire. Washington, DC: Woodrow Wilson Center Press, 2010.

Lincoln, Bruce. Theorizing Myth. Chicago: University of Chicago Press, 1999. 
Malinowski, Bronislaw. “Magic, Science and Religion.” In Magic, Science and Religion, edited by R. Redfield. New York City: Doubleday, 1948.

Rorty, Richard. Philosophy and Social Hope. London: Penguin, 2000.

Sheiko, Konstantin, and Stephen Brown, eds. History as Therapy: Alternate History and Nationalist Imaginings in Russia, 1991-2014. Stuttgart: ibidem, 2014.

Taylor, Charles. "Interpretation and the Sciences of Man." In Philosophy and the Human Sciences: Philosophical Papers, edited by C. Taylor, 15-57. Cambridge: Cambridge University Press, 1985.

Taylor, Charles. "Understanding and Ethnocentricity." In Philosophy and the Human Sciences: Philosophical Papers, edited by C. Taylor, 116-33. Cambridge: Cambridge University Press, 1985. 